\title{
Work incidents with biological material in the nursing team of a hospital in Mid-Western Brazil
}

\author{
Acidentes de trabalho com material biológico na equipe de enfermagem de um hospital do \\ Centro-Oeste brasileiro
}

Trabajar accidentes con material biológico en el personal de enfermería en un hospital de la región central de Brasil

\author{
Dayra Cabral de Carvalho \\ Jessica Cavalcante da Rocha ${ }^{1}$ \\ Mariane Carli de Almeida Gimenes ${ }^{2}$ \\ Ediálida Costa Santos ${ }^{1}$ \\ Marília Duarte Valim ${ }^{1}$
}

1. Universidade Federal de Mato Grosso.

Cuiabá, MT, Brazil.

2. Hospital Universitário Júlio Muller.

Cuiabá, MT, Brazil.
Corresponding author:

Mariane Carli de Almeida Gimenes.

E-mail: marianecarli@msn.com

Submitted on 05/16/2017.

Accepted on 09/30/2017.

DOI: 10.1590/2177-9465-EAN-2017-0140

\begin{abstract}
Objectives: To investigate and describe the occurrence and characteristics of Work Incidents (WI) with Potentially Contaminated Biological Material (PCBM), the frequency and variables related to this occurrence among nursing categories. Methods: A descriptive and cross-sectional study with a quantitative approach was performed at a referral hospital in the State of Mato Grosso, Mid-Western Brazil. Results: Women represented $90.5 \%$ of all participants and the mean age was 42.59 years. A total of $46.6 \%$ of professionals reported having undergone exposure to PCBM, $60.9 \%$ stated not having made a report, and $42.6 \%$ reported having participated in training courses on this subject. Comparing the occurrence of WI between nursing assistants and nurses, nursing assistants were more affected $(p=0.022)$. Conclusions: Among nursing professionals, the number of WI is high, recurrent and underreported. Continuing education on this theme is required to ensure the quality of care and promote workers' health.
\end{abstract}

Keywords: Work incident; Worker's health; Nursing team.

\section{Resumo}

Objetivos: Investigar e descrever a ocorrência e as características dos Acidentes de Trabalho (AT) com Material Biológico Potencialmente Contaminado (MBPC), a frequência e as variáveis relacionadas à ocorrência entre as categorias de enfermagem. Método: Estudo descritivo, transversal, de abordagem quantitativa, realizado em um hospital referência no estado de Mato Grosso, Brasil. Resultados: As mulheres representaram 90,5\% dos participantes e a média de idade foi de 42,59 anos. Um tota de $46,6 \%$ dos profissionais relatou já ter sofrido exposição a MBPC, e 60,9\% referiram não ter realizado a notificação e 42,6\% afirmaram terem participado de treinamentos sobre a temática. Na comparação entre a ocorrência de AT entre os grupos de enfermeiros e auxiliares de enfermagem, os auxiliares foram mais acometidos $(p=0,022)$. Conclusão: Nos profissionais de enfermagem, o número de AT é elevado, recorrente e subnotificado. A educação permanente relacionada à temática é necessária para garantir a qualidade da assistência e promover a saúde do trabalhador.

Palavras-chave: Acidente de trabalho; Saúde do trabalhador; Equipe de enfermagem.

\section{Resumen}

Objetivos: Evaluar y describen la ocurrencia y características de los accidentes industriales (AT) potencialmente contaminados con material biológico (MBPC), la frecuencia y las variables relacionadas con la aparición de la categoría de enfermería. Método: Estudio descriptivo transversal, con abordaje cuantitativo, realizado en Hospital referencia en el Estado de Mato Grosso, Brasil. Resultados: Las mujeres representaban el $90,5 \%$ de los participantes; la edad media fue de 42,59 años. Un total de 46,6\% de los encuestados reportó haber sufrido exposición a MBPC, y el 60,9\% no había hecho la notificación, el 42,6\% dijo que había participado en una formación sobre el tema. La comparación de la ocurrencia de AT entre los grupos de las enfermeras y auxiliares de enfermería, auxiliares fueron los más afectados $(p=0,022)$. Conclusión: En los profesionales de enfermería, e número de AT es elevado, recurrente y subnotificado. La educación permanente relacionada con la temática es necesaria para garantizar la calidad de la asistencia y promover la salud del trabajador.

Palabras clave: Accidente de trabajo; Salud Ocupacional; El personal de enfermería. 


\section{INTRODUCTION}

Work incidents (WI) with Potentially Contaminated Biological Material (PCBM) among workers of health institutions is still frequent and it can lead to serious physical and psychosocial consequences for victims and health institutions, such as the increase in the absenteeism rates and resulting financial losses. Thus, safer practices must be promoted in the work process, with an emphasis on health promotion and prevention of such problems. ${ }^{1,2}$

Standard Precautions (SP) are measures recommended by the Centers for Disease Control and Prevention (CDC). They must be followed universally by all professionals who provide health care, aiming to reduce the risks of contamination by biological agents and prevent Health Care-Related Infections (HCRI). ${ }^{3}$

Workers must know how to identify the risks inherent in each procedure and the importance of adherence to SP, thus acknowledging these measures as a way to decrease the risks of occupational exposure. ${ }^{3}$

Standard Precautions aim to protect professionals against PCBM transmitted by blood, bodily fluids and secretions (except for sweat) and to reduce the risk of HCRI. ${ }^{4}$

These SP include the following: 1) Hand Hygiene $(\mathrm{HH}) ; 2)$ The use of Personal Protective Equipment (PPE) such as gloves, white coats, protective goggles and masks; 3) Safe injection practices; 4) Safe manipulation of equipment or surfaces in the environment; and 5) cough etiquette. ${ }^{3}$ Thus, measures such as $\mathrm{HH}$ are considered to be the main strategy, aimed at preventing $\mathrm{HRCl}$. The purpose of PPE is to protect workers against exposure or contact with PCBM, whose selection is based on the nature of the professional-patient interaction, with potential exposure to blood, bodily fluids or infectious agents. ${ }^{5}$

Several studies identified the low use of SP to be directly associated with the level of knowledge and awareness of the risks of such measures. ${ }^{6}$ Certain factors that also have an impact on adherence as facilitators are continuing health education and training on this theme. ${ }^{7}$

A study on professionals' knowledge about biological agents, performed in the city of Rio de Janeiro, found out that only $39.8 \%$ of 266 individuals interviewed had been trained on SP. Additionally, this study revealed that $59 \%$ of participants reported lack of attention, lack of technical preparation, and lack of use of PPE as recommended, which led to the main causes associated with piercing-cutting incidents. ${ }^{8}$

Likewise, a study performed in a university hospital in the countryside of the state of Paraíba, Northeastern Brazil, aimed at questioning nursing professionals about the existence of a post-exposure-to-PCBM protocol, showed that only $37.5 \%$ stated that they knew this existed. However, this protocol could not be found in the sector investigated, nor could a documented record of such incidents. ${ }^{9}$
As the literature emphasizes the fact that knowledge about and adherence to SP are below the recommendations ${ }^{5}$ and that work incidents with PCBM are frequent in health institutions, ${ }^{10}$ the present study was performed due to the need to investigate the occurrence and variables associated with this type of incidents.

A study performed with health workers in a university hospital of Tehran, Iran, found a total of $53.4 \%$ of exposures to PCBM, with piercing-cutting incidents being the most frequent, followed by mucosa exposure. ${ }^{11}$ In the state of Mato Grosso do Sul, Mid-Western Brazil, a study emphasized the increase in WI reports with exposure to PCBM between 2007 and 2010 and the professions most frequently affected were nursing technicians, followed by nursing assistants. ${ }^{12}$ Given the importance of this theme and the high rates of occurrence of occupational exposure to biological materials, the present study aimed to investigate and describe the occurrence and characteristics of WI with PCBM involving nursing team professionals in a large city of the state of Mato Grosso, Mid-Western Brazil.

\section{METHODS}

A descriptive and cross-sectional study with a quantitative approach was performed. This research project was approved by the Research Ethics Committee of a University Hospital under protocol number 1653171.

This study was performed with nursing workers in a public hospital, considered to be a regional referral hospital in a large city of the state of Mato Grosso, Mid-Western Brazil, between October and December 2016. This hospital did not have a schedule for continuing education activities for SP, the use of safety devices had been recently implemented in the service, and the Comissão Interna de Prevenção de Acidentes (CIPA Internal Committee on Incident Prevention) had been created in June 2017.

The sample size $(n)$ of the present study was calculated considering the proportion of $0.5(p=0.5)$, as the outcome prevalence was unknown, using the following expression based on the population size $(\mathrm{N}) \cdot{ }^{13,14}$

$$
n=\frac{N p(1-p)}{(N-1)\left(d^{2} / Z_{\alpha / 2}^{2}\right)+p(1-p)}
$$

According to the information from the human resource sector of the previously mentioned institution, in 2015, the nursing team was comprised of 290 nursing professionals, of which 81 were nurses, 155 were nursing technicians and 55 were nursing assistants.

With this calculation, a minimum sample of 170 professionals was obtained through a random selection. It should be emphasized that the sample sought to follow the proportion of nurses, nursing technicians and nursing assistants according 
to the most recent studies published by the Federal Nursing Council, ${ }^{15,16}$ whose results totaled 22,635 nursing professionals in the state of Mato Grosso, of which $27.8 \%$ were nurses and $72.2 \%$ were nursing technicians and assistants. Likewise, this sample considered the proportions of professionals according to the numbers in their work sectors.

Professionals with more than six months of professional experience were selected for the present study. On the other hand, the following were excluded: professionals who had been away from their workplace; those who performed administrative tasks exclusively; and those who were participating in any training courses related to safety measures at the moment of data collection.

The units included in this study were as follows: blood bank, surgical clinic, infectious disease clinic, medical clinic, orthopedic clinic, Burn Treatment Center, isolation ward, children's yellow room, suture room, red room, and adult and pediatric Intensive Care Unit (ICU).

Regarding data collection, the self-applicable questionnaire with 15 yes/no questions and multiple choice questions was distributed in unidentified opaque envelopes with the Informed Consent Form. Thus, workers were instructed to respond to the questionnaire after their work activities. Questionnaires were collected by researchers in the following session, so that their work routine was not affected and their responses showed higher reliability. Mean time of completion was approximately ten minutes. Professionals who did not accept to participate in the study and those who, after three attempts by the researcher, did not return the envelope with the completed questionnaire were considered to be refusals.

The instrument used for data collection was validated for face and content by judges from the workers' health area, developed and used in previous studies. ${ }^{2}$ The following variables were investigated: frequency of incidents in the institution, report on the last incident, participation in training courses on SP measures provided by the employing institution, adequate replacement of the container used to dispose of piercing-cutting material when $2 / 3$ of its capacity are reached, vaccination against hepatitis B, and use of specific shoes for the work environment, in accordance with the existing laws.

Data were processed and analyzed with the SPSS software, version 16.0 for Windows 7.0. For data compilation, the double entry technique was used to minimize possible typographical errors. Numerical values were described through descriptive statistics, when the mean, median and standard deviation (SD) were calculated. Nominal categorical variables were described or shown in frequency tables.

The occurrence and reporting of $\mathrm{Wl}$ among the professional categories of nurses, nursing technicians and nursing assistants were assessed to identify possible statistically significant differences. Thus, Pearson' chi-square test was used to analyze the association between variables and Fisher's exact test was applied when the normality conditions for the use of this test were not found. Results were considered to be statistically significant with a $p \leq 0.05$.

\section{RESULTS}

The response rate was $87 \%$, as 148 professionals returned with adequately completed questionnaires. Thus, there was a sample loss of $12.94 \%$ due to incompleteness of most information and/or questionnaires not returned after three attempts.

Women totaled $90.5 \%$ of participants of the present study. Mean age was 42.59 years $(S D=9.42)$ and age ranged from 26 to 68 years. Nursing technicians totaled $65.5 \%$ of professionals as shown in Table 1, which also includes their allocation in the respective institutional sectors. The results show that nurses, nursing technicians and nursing assistants represented $29.7 \%$, $65.6 \%$ and $4.7 \%$ of the total, respectively.

According to Table 2, WI with piercing-cutting materials showed high rates in the institution analyzed, as $46.6 \%$ of the sample reported having been exposed to PCBM during their work activities in the previously mentioned institution. Of these, 35.1\% had WI with piercing-cutting materials and $30.4 \%$ through the mucosa or non-intact skin. Special attention should be given to the findings of the present study, as $63.5 \%$ of all those who had had incidents reported having two or more such incidents. Data from Table 2 showed that only $60.9 \%$ of professionals who had had incidents with PCBM said that they had given the required report on the last WI.

Table 3 shows that only $42.6 \%$ of professionals participated in training courses on SP and, of these, only $19 \%$ reported that the last course had been held in 2016, when data were collected for the present study. Additionally, there had been training courses in previous years. Between 2008 and 2015, there was a total of 36 professionals who received a qualification course $(57.1 \%)$ and $15(23.8 \%)$ who did not respond to this information.

Only $64.9 \%$ of professionals replaced the container for disposable piercing-cutting materials when $2 / 3$ of it were full. Regarding the use of PPE, only 95 workers (64.2\%) reported wearing waterproof and slip-resistant closed shoes, according to the standards of the Norma Regulamentadora (NR-32 Regulatory Norm).

It should be emphasized that a total of ten professionals (6.8\%) reported not receiving complete and adequate vaccination against Hepatitis B. Likewise, 19 professionals (12.8\%) reported not knowing their vaccination status, i.e. they disregarded whether they had actually been immunized with the presence of anti-HBs antibodies. When their knowledge about the presence of anti-HBs antibodies was assessed, $92(71.3 \%)$ of workers affirmed that the test result was negative, showing that either they were not aware of their immune response or they did not understand the question asked. 
Table 1. Distribution of nursing professionals $(n=148)$ according to sex, age group, level of education, professional category, type of work in the institution, and hospital work sector in a large city of the State of Mato Grosso, Mid-Western Brazil, 2016.

\begin{tabular}{|c|c|c|}
\hline Variable & $\mathbf{N}$ & $\%$ \\
\hline \multicolumn{3}{|l|}{ Sex } \\
\hline Male & 14 & 9.5 \\
\hline Female & 134 & 90.5 \\
\hline \multicolumn{3}{|l|}{ Age group (years) } \\
\hline $26-30$ & 15 & 10.4 \\
\hline $31-40$ & 52 & 36.1 \\
\hline $41-50$ & 52 & 36.1 \\
\hline$\geq 51$ & 25 & 17.4 \\
\hline \multicolumn{3}{|l|}{ Level of education } \\
\hline Primary education & 4 & 2.7 \\
\hline Secondary education & 43 & 29.1 \\
\hline Incomplete higher education & 31 & 20.9 \\
\hline Higher education & 35 & 23.6 \\
\hline Incomplete specialization & 5 & 3.4 \\
\hline Specialization & 28 & 18.9 \\
\hline Master's degree & 2 & 1.4 \\
\hline \multicolumn{3}{|l|}{ Professional category } \\
\hline Nurse & 44 & 29.7 \\
\hline Nursing technician & 97 & 65.6 \\
\hline Nursing assistant & 7 & 4.7 \\
\hline \multicolumn{3}{|l|}{ Type of work at the institution } \\
\hline Nurse & 32 & 21.6 \\
\hline Nursing technician & 101 & 68.2 \\
\hline Nursing assistant & 15 & 10.1 \\
\hline \multicolumn{3}{|l|}{ Work sector } \\
\hline Blood bank & 2 & 1.4 \\
\hline Surgical clinic & 9 & 6.2 \\
\hline Infectious disease clinic & 2 & 1.4 \\
\hline Medical clinic & 36 & 24.7 \\
\hline Orthopedic clinic & 5 & 3.4 \\
\hline Pediatric clinic & 19 & 13.0 \\
\hline Burn Treatment Center & 6 & 4.1 \\
\hline Isolation ward & 2 & 1.4 \\
\hline Children's Yellow Room & 6 & 4.1 \\
\hline Suture Room & 2 & 1.4 \\
\hline Red Room & 11 & 7.5 \\
\hline Suture & 1 & 0.7 \\
\hline Adult ICU & 37 & 25.3 \\
\hline Pediatric ICU & 8 & 5.5 \\
\hline
\end{tabular}

Table 2. Occurrence of incidents with potentially contaminated biological materials caused by piercing-cutting materials, exposure of mucosa and non-intact skin, report on the last incident, reasons for not reporting and frequency of reports in a large city of the State of Mato Grosso, Mid-Western Brazil, 2016.

\begin{tabular}{|c|c|c|}
\hline Variable & $\mathbf{N}$ & $\%$ \\
\hline \multicolumn{3}{|l|}{$\begin{array}{l}\text { Work incident with exposure to biological } \\
\text { material }\end{array}$} \\
\hline No & 79 & 53.4 \\
\hline Yes & 69 & 46.6 \\
\hline \multicolumn{3}{|l|}{ Incidents with piercing-cutting objects } \\
\hline No & 96 & 64.9 \\
\hline Yes & 52 & 35.1 \\
\hline \multicolumn{3}{|l|}{ If so, how many times } \\
\hline 1 time & 17 & 32.7 \\
\hline 2-3 times & 24 & 46.2 \\
\hline 4-5 times & 5 & 9.6 \\
\hline$\geq 6$ times & 4 & 7.7 \\
\hline Did not respond & 2 & 3.8 \\
\hline \multicolumn{3}{|l|}{$\begin{array}{l}\text { Incidents with exposure to the mucosa } \\
\text { and non-intact skin }\end{array}$} \\
\hline No & 103 & 69.6 \\
\hline Yes & 45 & 30.4 \\
\hline \multicolumn{3}{|l|}{ If yes, how many times } \\
\hline 1 time & 15 & 33.3 \\
\hline 2-3 times & 20 & 44.4 \\
\hline 4-5 times & 5 & 11.1 \\
\hline$\geq 6$ times & 1 & 2.2 \\
\hline Did not respond & 4 & 8.9 \\
\hline \multicolumn{3}{|l|}{ Report of the last incident } \\
\hline Did not respond & 02 & 2.9 \\
\hline Yes & 42 & 60.9 \\
\hline No & 25 & 36.2 \\
\hline \multicolumn{3}{|l|}{ Reason for not reporting } \\
\hline Report was not necessary & 7 & 28.0 \\
\hline There are no reporting services & 3 & 12.0 \\
\hline Did not realize the incident at the time & 9 & 36.0 \\
\hline Other reasons & 4 & 16.0 \\
\hline Did not respond & 2 & 8.0 \\
\hline \multicolumn{3}{|l|}{ Frequency of reporting } \\
\hline Always & 32 & 46.4 \\
\hline Frequently & 11 & 15.9 \\
\hline Sometimes & 6 & 8.7 \\
\hline Rarely & 5 & 7.2 \\
\hline Never & 8 & 11.6 \\
\hline Did not respond & 7 & 10.7 \\
\hline
\end{tabular}


Table 3. Frequency of participation in training courses on Standard Precaution (SP) measures, willingness to participate, replacement of container for disposables and use of specific shoes, vaccination scheme, knowledge about vaccination status and test results in a large city of the State of Mato Grosso, Mid-Western Brazil, 2016.

\begin{tabular}{lcc}
\hline Variable & N & $\%$ \\
\hline Participation in training courses & & \\
\hline No & 78 & 52.7 \\
Yes & 63 & 42.6 \\
Did not respond & 7 & 4.7 \\
\hline $\begin{array}{l}\text { Willingness to participate in training } \\
\text { courses }\end{array}$ & \\
\hline No & 12 & 8.1 \\
Yes & 136 & 91.9 \\
\hline Replacement of container of disposables & & \\
\hline No & 52 & 35.1 \\
Yes & 96 & 64.9 \\
\hline Use of specific shoes & & \\
\hline No & 53 & 35.8 \\
Yes & 95 & 64.2 \\
\hline Vaccination scheme & & \\
\hline No & 10 & 6.8 \\
Yes & 138 & 93.2 \\
\hline Knowledge about vaccination status & & \\
\hline No & 19 & 12.8 \\
Yes & 129 & 87.2 \\
\hline Test result & & \\
\hline Positive & 26 & 20.2 \\
Negative & 92 & 71.3 \\
Does not know & 11 & 8.5 \\
\hline
\end{tabular}

The categories of nursing assistants, nursing technicians and nurses were compared to each other in terms of occurrence and reporting of WI. There was a statistically significant difference in the occurrence of incidents with PCBM between nursing assistants and nurses $(p \leq 0.05)$. These data are shown in Table 4.

\section{DISCUSSION}

The distribution of all participants into the nursing team categories of the present study is in agreement with the proportion of recent studies performed in the State of Mato Grosso ${ }^{15,16}$ and researchers paid attention to this point so that statistical inferences associated with the study could be made with such support.
The results of the present study show that a high prevalence of women is still observed in nursing, similar to the prevalence found in Brazil. This has been the case since the beginning of this profession, as nursing care has been mainly performed by women. ${ }^{17}$ Women's social role has contributed to the feminization of this profession, as they have historically played the role of caregivers. ${ }^{18}$

The present study found that $46.6 \%$ of professionals had had incidents with exposure to PCBM, $35.1 \%$ of which occurred while they handled piercing-cutting objects. The literature shows that WI with piercing-cutting objects frequently occur among nursing professionals during the exercise of their activities, as they handle needles, intravenous catheters, blades and other materials used in technical procedures for health care on a daily basis. ${ }^{19}$

A study performed in a university hospital in the countryside of the state of São Paulo, which aimed to analyze the occurrence, characteristics and consequences of WI with an exposure to PCBM, found that $30.4 \%$ of nursing workers had had incidents at the moment when venipuncture was performed. Among the main consequences resulting from occupational exposure, $67.98 \%$ of workers mentioned that their incident caused concern, fear of possible HIV and viral hepatitis seroconversion, discomfort due to chemoprophylaxis, relevant emotional lack of control and family problems. ${ }^{20}$

Of all incidents with PCBM, $63.5 \%$ had had two or more incidents, an alarming fact as the WI were recurring. In this sense, a study performed in a pre-hospital service in the state of Minas Gerais revealed that, of all professionals who had had incidents with exposure to PCBM, $67.5 \%$ reported one exposure; $19.3 \%$, two exposures; and $13.2 \%$, three exposures to PCBM. ${ }^{6}$

Another alarming factor found in the present study was that $36.2 \%$ of workers who had had incidents did not report their last exposure to PCBM. In agreement with these findings, some studies have confirmed that not reporting $\mathrm{Wl}$ is a common practice among Brazilian workers. Thus, surveillance and control of WI with PCBM must be improved. Additionally, reporting must be encouraged by health institution management, as there are no accurate data on the number of occurrences of HIV and hepatitis $\mathrm{B}$ and $\mathrm{C}$ seroconversion among health professionals in Brazil and incidents continue to be frequent in recent years. ${ }^{2,21,22}$

The present study observed that the Work Incident Report (CAT - Comunicação do Acidente de Trabalho) had not been issued and the Sistema de Informação de Agravos de Notificação (SINAN-NET - Information System on Notifiable Diseases) form had not been completed correctly. This behavior leads to untrue information which is incompatible with the reality of official reports, thus emphasizing the importance of workers being included in the work process as an ally and modifying agent. ${ }^{22-24}$ Many health professionals are incapable of assessing the importance of reporting WI with PCBM and they also disregard the recommended measures, causing them to become more vulnerable to biological contamination. ${ }^{27}$ 
Table 4. Distribution of nursing professionals per professional category, according to occurrence of work incident and reporting of the last incident in a large city of the State of Mato Grosso, Mid-Western Brazil, 2016.

\begin{tabular}{|c|c|c|c|c|c|}
\hline & \multicolumn{4}{|c|}{ Work incident } & \multirow{3}{*}{$p$ value } \\
\hline & \multicolumn{2}{|c|}{ No } & \multicolumn{2}{|c|}{ Yes } & \\
\hline & $\mathbf{N}$ & $\%$ & $\mathbf{N}$ & $\%$ & \\
\hline Nurse & 22 & 68.8 & 10 & 68.8 & $0.0867^{*}$ \\
\hline Nursing technician & 52 & 51.5 & 49 & 48.5 & \\
\hline Nurse & 22 & 68.8 & 10 & 68.8 & $0.0221^{*}$ \\
\hline Nursing assistant & 5 & 33.3 & 10 & 66.7 & \\
\hline Nursing technician & 52 & 51.5 & 49 & 48.5 & $0.1895^{*}$ \\
\hline \multirow[t]{4}{*}{ Nursing assistant } & 5 & 33.3 & 10 & 66.7 & \\
\hline & \multicolumn{4}{|c|}{ Reporting of the last incident } & \\
\hline & \multicolumn{2}{|c|}{ No } & \multicolumn{2}{|c|}{ Yes } & $p$ value \\
\hline & $\mathbf{N}$ & $\%$ & $\mathbf{N}$ & $\%$ & \\
\hline Nurse & 2 & 20.0 & 8 & 80.0 & $0.2763 * *$ \\
\hline Nursing technician & 17 & 34.7 & 30 & 61.2 & \\
\hline Nurse & 2 & 20.0 & 8 & 80.0 & $0.0849 * *$ \\
\hline Nursing assistant & 6 & 60.0 & 4 & 40.0 & \\
\hline Nursing technician & 17 & 34.7 & 30 & 61.2 & $0.1494 * *$ \\
\hline Nursing assistant & 6 & 60.0 & 4 & 40.0 & \\
\hline
\end{tabular}

* Application of Pearson's chi-square test; ** Application of Fisher's exact test.

The data shown emphasize the need for continuing education actions aimed at the theme of prevention of occupational risks and recognition and avoidance of neglect for work incidents. Moreover, the role of managers in the promotion of workers' health stands out with the adoption of prevention and protection policies and acquisition of sufficient and adequate material resources. ${ }^{25,26}$

The findings show that a total of $35.8 \%$ of workers reported not wearing closed shoes, as recommended by the NR-32. A study performed in a university hospital in the countryside of the state of São Paulo found that $2.7 \%$ of all work incidents investigated showed the lower limbs as the body part affected. This could be prevented with the adequate use of PPE, such as waterproof and slip-resistant closed shoes. Likewise, professionals must not wear these shoes out of the institution where they provide care, aiming to prevent pathogen transmission. ${ }^{28}$ It should be emphasized that the NR-32 aims to protect and promote health workers' health and recommends, among other measures, that these workers should not wear open shoes or accessories, smoke or eat in the workplace. ${ }^{29,30}$

Another situation that poses a risk to health professionals is associated with the adequate replacement of containers for disposable piercing-cutting materials, as only $64.9 \%$ of them performed this action correctly, when $2 / 3$ of it were full. A study that analyzed the team of nursing assistants and technicians' knowledge about handling and segregation of piercing-cutting objects found that $60 \%$ of interviewees reported following the current recommendations. However, reports of workers showed that there were questions about how full the container should be, as participants argued that it must not be overfilled, ${ }^{31}$ an action that can expose the health team to higher risks of incidents.

Regarding knowledge about the vaccination response to Hepatitis B, workers showed lack of knowledge and, as a result, higher exposure to risks that could be prevented. Nursing workers in particular were more vulnerable to hepatitis, flu, mumps, rubella, chickenpox, tuberculosis, and immunebiologically preventable infections and, for this reason, adequate immunization and knowledge about vaccination response should be encouraged. ${ }^{23}$

Additionally, there was a statistically significant difference in the occurrence of $\mathrm{Wl}$ among nursing assistants, when compared to nurses. In this context, the literature indicates that nursing assistants are more susceptible to the occurrence of WI, due to the extended working hours, exhausting direct care demand and routine, and lack of knowledge and difficulty to perform the technique in a safe way. ${ }^{23}$

Due to the higher statistical significance of WI with PCBM among these professional categories, health education actions must occur in the context of one's professional practice in a permanent, constant and routine way, regardless of professional category and work. 
The perception of risks causes health professionals to adhere to the SP in all situations. Additionally, continuing health education must be promoted, aiming to produce conscious attitudes and guarantee workers' protection. ${ }^{32,33}$ Through continuing health education, researchers expect to obtain changes in work practice and technical and scientific knowledge about workers' health safety and promotion and disease prevention and the resulting patient safety. ${ }^{34}$

Based on this context, health institution managements are expected to be committed to supporting professionals as they adhere to safe practices through continuing health education. A study performed in a city in the countryside of the State of São Paulo emphasized that, with high-quality educational actions, it is possible to provide support so that higher levels of adherence to SP can be achieved, taking into consideration the practice of each service/sector and the participation of a nurse supervisor on an individual and group level. ${ }^{32}$

\section{CONCLUSION}

Work incidents with exposure to biological material are still frequent, recurrent and underreported in the health institution investigated, an alarming reality that requires health education interventions. Although the "nursing assistants" category showed a statistically significant difference in occurrence of incidents, preventive actions for workers' health promotion and disease prevention are needed in all categories and actions of nursing professionals.

The search for knowledge, the importance of constant participation of the nursing team in continuing education on the theme of incident prevention, and the adoption of safe behavior are essential strategies to guarantee the quality of health care and workers' health promotion.

Thus, the best qualification and continuing education must be offered to health workers, because the realities and technologies connected to health have experienced constant changes throughout history. Nursing professionals need to be ready to follow the advances in this area, so that they can perform work activities aimed at the quality of the health care provided.

Additionally, as this was a cross-sectional study with a selfadministered instrument, it is well known that data reliability can be influenced by participants' subjectivity and memory bias. Likewise, once the instrument did not include a period of time for further evidence and standardization of the occurrence of WI with PCBM (previous year or six months, for example), future studies must investigate the incidence of $\mathrm{Wl}$ in the previously mentioned institution during these periods of time. Furthermore, this is a way to analyze the efficacy of continuing education actions related to this theme. It should be emphasized that the present study was performed in only one health institution, which can compromise data generalization and representativeness of the population of nursing team professionals.

\section{REFERENCES}

1. Marziale MHP, Santos HEC, Cenzi CM, Rocha FLR, Trovó MEM Consequências da exposição ocupacional a material biológico entre trabalhadores de um hospital universitário. Esc Anna Nery [Internet] 2014 Jan/Mar; [cited 2016 Nov 10]; 18(1):11-6. Available from: http:// www.redalyc.org/pdf/1277/127730129002.pdf

2. Valim MD, Marziale MHP, Hayashida M, Richart-Martínez M. Ocorrência de acidentes de trabalho com material biológico potencialmente contaminado em enfermeiros. Acta Paul Enferm [Internet]. 2014; [cited 2017 Jan 10]; 27(3):280-6. Available from: https://rua.ua.es/dspace/ bitstream/10045/40680/2/2014_Duarte_etal_ActaPaulEnferm_por.pdf

3. Centers for Disease Control and Prevention (CDC). Guide to infection prevent for out patient settings: Minimum expectations for safe care. [Internet]. 2015 [cited 2016 Aug 14]; Available from: https://www.cdc. gov/hai/settings/outpatient/outpatient-care-guidelines.html

4. Siegel JD, Rhinehart E, Jackson M, Chiarello L; Health Care Infection Control Practices Advisory Committee. 2007 Guideline for Isolation Precautions: Preventing Transmission of Infectious Agents in Health Care Setting. Am J Infect Control [Internet]. 2007 Dec; [cited $2016 \mathrm{Jul}$ 27]; 35(10 Suppl 2):S65-164. Available from: http://www.ajicjournal.org/ issue/S0196-6553(07)X0153-6

5. Ghonim E, Ghonim ER, Nolan R, Baumann MH. Hand Hygiene:There's an app for that? Am J Infect Control [Internet]. 2012 Jun; [cited 2016 Aug 14]; 40(5):e86-7. Available from: http://www.ajicjournal.org/article/ S0196-6553(12)00428-2/pdf

6. Oliveira AC, Paiva MHRS. Prevalência e características dos acidentes com material biológico envolvendo profissionais do atendimento préhospitalar móvel. Cienc Cuid Saúde [Internet]. 2013 Apr/Jun; [cited 2016 Jul 27]; 12(2):323-30. Available from: http://ojs.uem.br/ojs/index. php/CiencCuidSaude/article/viewFile/19371/pdf

7. Valim MD, Maeziale MHP, Hayashida M, Rocha FLR, Santos JLF Validade e confiabilidade do Questionário de Adesão às Precauçõespadrão. Rev Saúde Pública [Internet]. 2015; [cited 2016 Jul 27]; 49(87):1 8. Available from: http://www.scielosp.org/pdf/rsp/v49/pt_0034-8910rsp-S0034-89102015049005975.pdf

8. Silva GS, Almeida AJ, Paula VS, Villar LM. Conhecimento e utilização de medidas de precaução-padrão por profissionais de saúde. Esc Anna Nery [Internet]. 2012 Mar; [cited 2017 Apr 2]; 16(1):103-10. Available from: http://www.scielo.br/scielo.php?script=sci_arttext\&pid $=$ S1414-81452012000100014

9. Campo SF, Vilar MA, Vilar DA. Biossegurança: Conhecimento e Adesão às Medidas de Precauções Padrão num Hospital. Rev Bras Ciênc Saúde [Internet]. 2011; [cited 2017 Jul 19]; 15(4):415-20. Available from: http:// periodicos.ufpb.br/ojs2/index.php/rbcs/article/viewFile/9830/6859

10. Castro MR, Farias SNP. Repercussões do acidente com perfurocortantes para a enfermagem: uma construção a partir do grupo focal. Esc Anna Nery [Internet]. 2009 Jul/Sep [cited 2017 Jan 25]; 13(3):523-9. Available from: http://www.redalyc.org/pdf/1277/127715325010.pdf

11. Shokuhi S, Gachkar L, Alavi-Darazam I, Yuhanaee P, Sajadi M. Occupational Exposure to Blood and Body Fluids among Health Care Workers in Teaching Hospitals in Tehran, Iran. Iran Red Crescent Med J [Internet]. 2012 Jul; [cited 2017 Sep 16]; 14(7):402-7. Available from: https://www.ncbi.nlm.nih.gov/pmc/articles/PMC3438432/

12. Martins AT, Oliveira CS, Ajalla MEA, Bonilha LAS, Lahdo V, Quirino TM. Acidentes de trabalho com exposição à material biológico registrados no estado de Mato Grosso do Sul, 2007 a 2010. Anais do 3o SITEN - Seminário Internacional sobre o Trabalho na Enfermagem; 13-11 Ago. 2011. [Internet]. Bento Gonçalves (RS), Brasil: ABEn; 2011. [cited 2017 Jul 19] p. 105-108. Available from: http://www.abeneventos.com. br/3siten/siten-trabalhos/files/0010.pdf

13. Bolfarine $\mathrm{H}$, Bussab WO. Elementos de amostragem. $1^{\text {a }}$ ed. São Paulo: Editora Edgar Blücher; 2005.

14. Espinosa MM, Rodrigues DC, Marcon SR. Planejamento amostral probabilístico em estudos comparativos com grupos de idosos. Connection Line [Internet]. 2015; [cited 2017 Jan 25]; (13):74-84 Available from: http://www.periodicos.univag.com.br/index.php/ CONNECTIONLINE/article/viewFile/247/487 
15. Conselho Federal de Enfermagem - COFEN (BR). Resolução Cofen № 423/2012. Normatiza, no Âmbito do Sistema Cofen/ Conselhos Regionais de Enfermagem, a Participação do Enfermeiro na Atividade de Classificação de Riscos. [Internet]. 2012; [cited 2017 Feb 10]. Available from: http://www.cofen.gov.br/resoluocofen-n-4232012_8956.html

16. Teixeira $P$, Valle S. Biossegurança: uma abordagem multidisciplinar. $2^{{ }^{\underline{a}}}$ ed. Rio de Janeiro: FIOCRUZ; 2010.

17. Gomes BS, Carvalho CA, Silva IB, Pereira LS, Gama MO, Jesus NS. A identidade profissional da enfermagem numa perspectiva de gênero. [Internet]. 2013 [cited 2017 Feb 10]; Universidade Federal da Bahia UFBA, CONVIBRA. Available from: http://www.convibra.com.br/upload/ paper/2013/80/2013_80_5723.pdf

18. Carrilo-García C, Solano-Ruíz MDC, Martínez-Roche ME, GómezGarcía Cl. Influência do gênero e da idade: satisfação no trabalho de profissionais da saúde. Rev Latino Am Enferm [Internet]. 2013 Nov/ Dec; [cited 2016 Dec 9]; 21(6):1314-20. Available from: http://www. journals.usp.br/rlae/article/view/76055/79752

19. Verçosa RCM, Monteiro VGN, Ferreira FAS. Acidentes com perfuro cortantes entre profissionais de enfermagem de um hospital universitário. Rev Enferm UFPE On Line [Internet]. 2014 Apr; [cited 2016 Dec 10]; 8(4):864-71. Available from: https://periodicos.ufpe.br/ revistas/revistaenfermagem/article/viewFile/9754/9873

20. Marziale MHP, Rocha FLR, Robazzi MLCC, Cenzi CM, Santos HEC, Trovó MEM. Influência organizacional na ocorrência de acidentes de trabalho com exposição a material biológico. Rev Latino Am Enferm [Internet]. 2013 Jan/Feb; [cited 2016 Dec 10]; 21(Spec): [8 telas]. Available from: http://www.journals.usp.br/rlae/article/ viewFile/52943/56944

21. Luo Y, HE GP, Zhou JW, Luo Y. Factors impacting compliance with standard precautions in nursing, China. Int J Infect Dis [Internet] 2010 Dec; [cited 2016 Dec 1]; 14(2010):e1106-14. Available from: http:// www.ijidonline.com/article/S1201-9712(10)02501-4/pdf

22. Valim MD, Marziale MHP. Evaluating occupational exposure to biological material in health services. Texto Contexto Enferm [Internet]. 2011; [cited 2016 Oct 10];20(Esp):138-46. Available from: http://www.scielo. br/pdf/tce/v20nspe/v20nspea18.pdf

23. Machado MRM, Machado FA. Acidentes com material biológico em trabalhadores de enfermagem do Hospital Geral de Palmas (TO). Rev Bras Saúde Ocup [Internet]. 2011; [cited 2016 Nov 10]; 36(124):274-81. Available from: https://www.fasul.edu.br/portal/app/webroot/files/links/ Seguran\%C3\%A7a\%20Trabalho/RBSO/RBSO\%20124\%20vol\%2036. pdf\#page $=90$

24. Oliveira QB, Santos RS, Santos CMF. Acidentes de trabalho na equipe de enfermagem: uma revisão de literatura. Rev Enferm Contemp. [Internet]. 2013 Aug; [cited 2017 Feb 10]; 2(1):32-52. Available from: https://www5.bahiana.edu.br/index.php/enfermagem/article/ viewFile/199/187
25. Magagnini MAM, Rocha AS, Ayres JA. O significado do acidente de trabalho com material biológico para os profissionais de enfermagem. Rev Gaúcha Enferm [Internet]. 2011 Jun; [cited 2017 Feb 10]; 32(2):3028. Available from: http://www.scielo.br/pdf/rgenf/v32n2/a13v32n2

26. Nowak NL, Campos GA, Borba EO, Ulbricht L, Neves EB. Fatores de risco para acidentes com materiais perfurocortantes. O Mundo da Saúde [Internet]. 2013; [cited 2016 Nov 1]; 37(4):419-6. Available from: https://www.saocamilo-sp.br/pdf/mundo_saude/155558/A06.pdf

27. Silva TR, Rocha SA, Ayres JA, Juliani CMCM. Acidente com material perfurocortante entre profissionais de enfermagem de um hospital universitário. Rev Gaúcha Enferm [Internet]. 2010; [cited 2016 Nov 1]; 31(4):615-22. Available from: https://repositorio.unesp.br/ handle/11449/11981

28. Marziale MHP, Galon T, Cassiolato FL, Girão FB. Implantação da Norma Regulamentadora 32 e o controle dos acidentes de trabalho. Acta Paul Enferm [Internet]. 2012; [cited 2016 Oct 25]; 25(6):859-66. Available from: http://www.producao.usp.br/bitstream/handle/BDPI/39166/ S0103-21002012000600006. pdf? sequence=1\&isAllowed=y

29. Ministério do Trabalho e Emprego (BR). Portaria no 485, de 11 de novembro de 2005. Aprova a Norma Regulamentadora no 32 (Segurança e saúde no trabalho em estabelecimentos de saúde). [Internet]. Brasília (DF): Diário Oficial da República Federativa do Brasil; 2005. [cited 2016 Jun 20]. Available from: http://sbbq.iq.usp.br/ arquivos/seguranca/portaria485.pdf

30. Conselho Federal de Enfermagem de Mato Grosso - COFEN-MT. Decisão Coren - MT №. 044/2008. [Internet]. [cited 2017 Feb 10]. Available from: http://mt.corens.portalcofen.gov.br/decisao-coren-mtno-0442008_750.html

31. Moura ECC, Moreira MFS, Fonseca SM. Atuação de auxiliares e técnicos de enfermagem no manejo de perfurocortantes: um estudo necessário. Rev Latino Am Enferm [Internet]. 2009 May/Jun; [cited 2017 Jul 16]; 17(3):321-7. Available from: http://www.scielo.br/scielo. php?script=sci_arttext\&pid=S0104-11692009000300007\&lng=en\&n $\mathrm{rm}=\mathrm{iso}$

32. Carvalho JFS, Chaves LDP. Supervisão de enfermagem no uso de equipamento de proteção individual em um hospital geral. Cogitare Enferm [Internet]. 2010 Jul/Sep; [cited 2016 Nov 14]; 15(3):513-20. Available from: http://revistas.ufpr.br/cogitare/article/view/18897/12205

33. Pereira FMV, Malaguti-Toffano SE, Silva AM, Canini SRMS, Gir E. Adesão às Precauções-padrão por profissionais de enfermagem que atuam em terapia intensiva em um hospital universitário. Rev Esc Enferm USP [Internet]. 2013; [cited 2016 Dec 1]; 47(3):686-93. Available from: http://www.periodicos.usp.br/reeusp/article/view/78012

34. Lacerda MKS, Souza SCO, Soares DM, Silveira BRM, Lopes JR Precauções padrão e Precauções Baseadas na Transmissão de doenças: revisão de literatura. Rev Epidemiol Control Infect [Internet]. 2014 Oct/Dec; [cited 2016 Nov 14]; 4(4):254-9. Available from: https:// online.unisc.br/seer/index.php/epidemiologia/article/view/4952 